\title{
Karakteristik Organoleptik dan Nilai pH Yoghurt dengan Penambahan Sari Buah Mengkudu (Morinda citrifolia L)
}

\author{
Organoleptic Characteristics and pH Value of Yogurt with Addition of Noni Fruit Extract \\ (Morinda citrifolia $\mathrm{L}$ ) \\ Rasbawati, Irmayani, I. D. Novieta \& Nurmiati \\ Program Studi Peternakan, Fakultas Pertanian, Peternakan dan Perikanan \\ Universitas Muhammadiyah Parepare \\ Jln. Jenderal Ahmad Yani Km 6 Lapadde, Parepare, 91113 \\ Email koresponden author: rasbawati@gmail.com
}

\begin{abstract}
Yogurt is a processed product which is the fermentation of milk by lactic acid bacteria. The use of noni fruit in the process of making yogurt is one of the efforts to diversify food. This study aims to determine the effect of Morinda citrifolia $L$ level extract on the characteristics and pH value of yogurt. The study used a completely randomized design (CRD) with 4 treatments (P0: 0\%, P1: 5\%; P2: 10\% and P3: 15\%) and the treatment was repeated 3 times. Observations were analyzed using variance analysis (ANOVA) and if there were significant differences, it would be followed by Duncan's Real Distance Difference test (Duncan's Multiple Range Test) to determine which treatment level gave a significant difference. The results showed that the addition of noni fruit extract had a very significant effect $(P<0.01)$ on the organoleptic characteristics and $\mathrm{pH}$ value of yogurt. The best results obtained in this study were the addition of noni fruit extract with a level of $10 \%$.
\end{abstract}

Keywords: Yoghurt, Noni fruit extract, pH value, Organoleptic

\section{PENDAHULUAN}

Upaya diversifikasi produk olahan dari susu kini semakin berkembang, hal ini disebabkan karena susu merupakan produk bernutrisi tinggi yang mudah mengalami kerusakan. Salah satu upaya untuk mengurangi kerusakan pada produk susu yaitu dengan melakukan fermentasi susu. Yoghurt merupakan salah satu produk fermentasi susu dengan bantuan bakteri asam laktat (BSN, 2009). Menurut Robertfroid (2000), bakteri asam laktat bermanfaat bagi tubuh karena menyeimbangkan bakteri dalam usus besar dan mengurangi resiko berkembangnya bakteri merugikan. Yoghurt dibedakan menjadi plain yoghurt dan fruit yoghurt. Plain yoghurt adalah yoghurt murni hasil fermentasi susu dengan menggunakan kultur Lactobacillus bulgaricus, Lactobacillus acidophillus dan Streptococcus thermophilus sedangkan Fruit yoghurt adalah yoghurt yang dalam proses pembuatannya dilakukan penambahan sari buah, daging buah, atau bagian buah lainnya sebagai penambah cita rasa, warna dan aroma sehingga meningkatkan sifat organoleptik yoghurt (Tamime dan Robinson, 2007). Salah satu buah yang dapat digunakan pada proses pembuatan yoghurt adalah mengkudu (Morinda citrifolia L).

Buah mengkudu (Morinda citrifolia L) di Indonesia masih tergolong kurang dimanfaatkan dibanding dengan buah lain. Hal ini dikarenakan buah mengkudu memiliki cita rasa yang kurang disukai oleh masyarakat dan memiliki aroma yang kurang sedap. Mengkudu (Morinda citrifolia L.) mengandung beberapa zat aktif utama. Bahan aktif diantaranya adalah scopoletin, octoanoic acid, kalium, vitamin C, alkaloid, antrakuinon, bsitosterol, karoten, vitamin A, glikosida flavon, linoleat acid, alizarin, amino acid, acubin, L asperuloside, kaproat acid, kaprilat acid, ursolat acid, rutin, pro-xeronine dan terpenoid (Wang et al., 2002). Mengkudu (Morinda citrifolia L) diketahui memiliki banyak manfaat untuk kesehatan manusia. Efek buah mengkudu diantaranya sebagai antitrombolitik, antioksidan, analgesik, anti inflamasi dan aktifitas xanthine oxidase inhibitor. Mengkudu juga dapat menurunkan tekanan darah dan vasodilatasi pembuluh darah (Ayanblu et al., 2006). Berdasarkan uraian di atas penelitian ini bertujuan untuk mengetahui pengaruh penambahan ekstrak buah mengkudu terhadap karakteristik organoleptik dan nilai $\mathrm{pH}$ yoghurt.

\section{MATERI DAN METODE}

\section{Materi}

Materi yang digunakan antara lain adalah susu murni yang diperoleh dari peternak sapi perah, buah mengkudu, gula merah, jahe, aquades, air, tissue, untuk membiakkan bakteri asam laktat peneliti menggunakan biokul sebagai starter. Alat yang digunakan meliputi $\mathrm{pH}$ meter, labu ukur, inkubator, lemari pendingin, blender, termometer dan timbangan digital. 


\section{Prosedur Penelitian}

Prosedur penelitian dilakukan dengan 2 tahapan, yaitu:

1. Pembuatan Ekstrak Buah Mengkudu

Sebanyak $600 \mathrm{~g}$ buah mengkudu tanpa cacat dicuci bersih dan dipotong kemudian diblansir pada suhu $65^{\circ} \mathrm{C}$ selama 2,5 menit setelah itu diblender dengan $600 \mathrm{ml}$ air, ekstraknya dipisahkan sebanyak $500 \mathrm{ml}$ ditambah $200 \mathrm{ml}$ larutan gula merah dan $14 \mathrm{ml}$ sari jahe. Campuran selanjutnya dimasukkan kedalam wadah steril dan mulut wadah ditutup menggunakan kain bersih. Pembuatan sari buah mengkudu difermentasi selama 2 hari (Muntia $d k k$, 2010 dengan modifikasi).

2. Proses Pembuatan Yoghurt dengan Penambahan Ekstrak Buah Mengkudu

Sebanyak 2 liter susu murni dipanaskan pada suhu $80^{\circ} \mathrm{C}$ selama 15 menit sambil diaduk perlahan. Susu kemudian didinginkan hingga suhu $43^{\circ} \mathrm{C}$. Kemudian ditambah $3 \%$ starter dan diinkubasi pada suhu $43^{\circ} \mathrm{C}$ selama 3 jam selajutnya, ditambahkan sari buah mengkudu sesuai perlakuan yakni sebesar 5\% (P1); $10 \%(\mathrm{P} 2) ; 15 \%(\mathrm{P} 3)$ dan diinkubasi kembali pada suhu $43^{\circ} \mathrm{C}$ selama 2 jam. Yoghurt yang dihasilkan didinginkan hingga suhu ruang dan dimasukkan kedalam lemari pendingin sampai akan digunakan.

\section{Pengukuran Nilai pH}

Pengukuran nilai $\mathrm{pH}$ dilakukan dengan $\mathrm{pH}$ meter elektronik. Sebelum pH meter elektronik digunakan, ujung katoda indikator dicuci dengan aquades, kemudian dibersihkan dengan tissue. Kemudian $\mathrm{pH}$ meter elektronik dikalibrasi dengan ujung katoda dicelupkan ke dalam larutan buffer 4 dan 7 (Wahyudi, 2006). Kemudian ujung katoda dicelupkan dalam sampel yoghurt dan setiap kali akan mengukur $\mathrm{pH}$ sampel yang lain probe dibersihkan menggunakan aquades terlebih dahulu Nilai yang dibaca adalah nilai saat $\mathrm{pH}$ meter telah stabil.

Pengujian Karakteristik Organoleptik

Pengujian terhadap sifat organoleptik yoghurt meliputi cita rasa, aroma, warna dan tekstur dilakukan dengan panelis semi terlatih sebanyak 15 orang dengan kisaran usia 19-25 tahun, pria atau wanita berstatus mahasiswa. Penilaian rasa, aroma, warna dan tekstur yoghurt disajikan dalam wadah plastik (ice cup). Kisaran skor yang diberikan 1 sampai 5 .

\section{Analisis Data}

Penelitian ini disusun menggunakan Rancangan Acak Lengkap (RAL) monofaktor dengan 4 taraf perlakuan dan 3 ulangan. Perlakuan yang diterapkan meliputi P0 (0\%), P1 (5\%), P2 (10\%) dan P3 (15\%). Variabel yang diamati adalah nilai $\mathrm{pH}$ dan karakteristik organoleptik (rasa, aroma, tekstur dan warna. Data dianalisis menggunakan metode analisis ragam (Analysis of Variant atau ANOVA) apabila ada pengaruh perlakuan dilanjutkan dengan uji Duncan. Data diolah dan dianalisis dengan bantuan program komputer dengan aplikasi SPSS versi 16 for windows pada taraf signifikan 5\%.

\section{HASIL DAN PEMBAHASAN}

\section{Nilai pH yoghurt dengan penambahan Sari Buah Mengkudu}

Nilai $\mathrm{pH}$ yoghurt pada penambahan sari buah mengkudu pada berbagai level yang berbeda dapat dilihat pada Gambar 1.

Berdasarkan hasil analisis ragam pada Gambar 1 menunjukkan bahwa penambahan sari buah mengkudu dengan level yang berbeda berpengaruh sangat nyata $(\mathrm{P}<0,01)$ terhadap nilai $\mathrm{pH}$ yoghurt. Nilai $\mathrm{pH}$ yoghurt tertinggi diperoleh pada perlakuan kontrol $(0 \%)$ dengan nilai 4,5 dan perlakuan P1 (5\%) sedangkan nilai $\mathrm{pH}$ terendah di peroleh pada penambahan sari mengkudu sebanyak 15\% (P3) dengan nilai 4,3. Nilai pH pada masingmasing perlakuan sudah sesuai dengan Food Standards Australia New Zealand (2014) bahwa pH yoghurt yang baik memiliki nilai maksimum 4,5. Selama fermentasi, BAL akan memproduksi asam laktat, asam sitrat, dan asam asetat

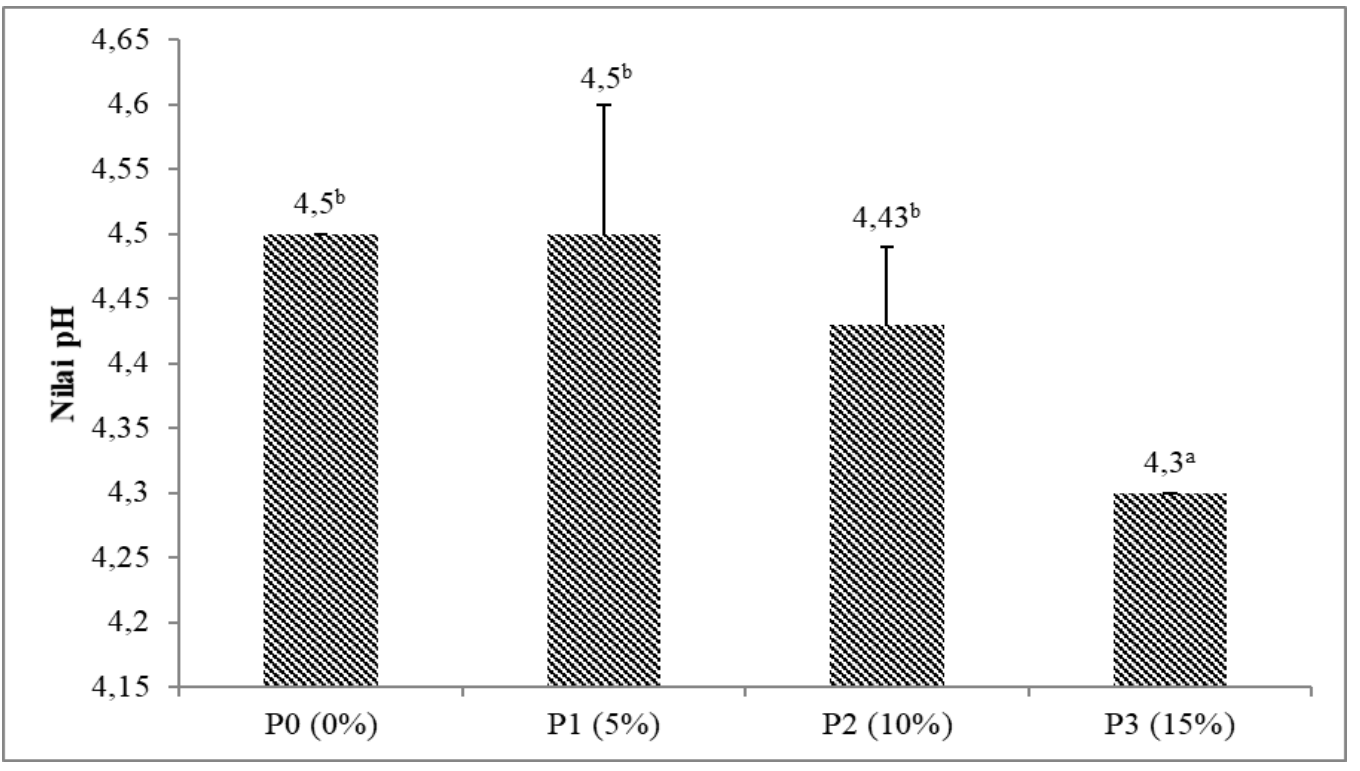

Gambar 1. Rata-rata pH yoghurt dengan penambahan ekstrak buah mengkudu dengan level yang berbeda 
yang akan menyebabkan $\mathrm{pH}$ yoghurt menurun (Surono, 2004). Asam organik yang terbentuk merupakan asam-asam yang terdisosiasi dalam bentuk ion-ion $\mathrm{H}^{+}$. Semakin banyak asam yang dihasilkan, maka semakin banyak pula ion $\mathrm{H}^{+}$ yang terbentuk sehingga pengukuran $\mathrm{pH}$ oleh elektroda $\mathrm{pH}$ meter menunjukkan nilai yang semakin menurun.

Semakin tinggi proporsi penambahan sari buah mengkudu (Morinda Citrifolia L) yang di tambahkan kedalam yoghurt maka nilai $\mathrm{pH}$ yoghurt yang dihasilkan semakin rendah. Penurunan $\mathrm{pH}$ disebabkan karena adanya peningkatan konsentrasi sari mengkudu yang bersifat asam dengan $\mathrm{pH}(3,3)$ sehingga berpengaruh terhadap penurunan $\mathrm{pH}$ yoghurt. Sari buah mengkudu dapat menstimulasi pertumbuhan BAL. Semakin banyak jumlah BAL maka semakin banyak hasil metabolit terutama berupa asam laktat yang dapat terdisosiasi dalam ion-ion $\mathrm{H}$ sehingga $\mathrm{pH}$ menjadi semakin rendah. Sifat asam yang dimiliki oleh sari buah mengkudu ini disebabkan adanya kandungan vitamin C (Shovic dan Whistler, 2001).

\section{Rasa Yoghurt}

Rasa yoghurt dengan penambahan Sari Buah Mengkudu pada level yang berbeda berdasarkan hasil uji organoleptik disajikan pada Gambar 2. Hasil analisis ragam menunjukkan bahwa penambahan sari buah mengkudu dengan level yang berbeda berpengaruh sangat nyata $(\mathrm{P}<0,01)$ terhadap rasa yoghurt. Nilai organoleptik rasa yoghurt dengan penambahan sari buah mengkudu berkisar 3,20 - 4,00 yaitu memiliki kriteria rasa yang asam. Nilai rasa yang tertinggi dihasilkan oleh perlakuan dengan penambahan konsentrasi sari buah mengkudu sebanyak (15\%), dengan nilai 4,00 sedangkan nilai terendah diperoleh oleh perlakuan kontrol ( $0 \%$ ) dengan nilai 3,20. Grafik yang mengambarkan hasil uji organoleptik terhadap rerata skor rasa yoghurt buah mengkudu disajikan pada Gambar 2.

Berdasarkan penilaian panelis terhadap rasa yoghurt menunjukkan bahwa semakin banyak proporsi penambahan sari buah mengkudu pada yoghurt maka rasa yoghurt semakin asam. Hal ini disebabkan karena sari buah mengkudu sudah sejak awal memiliki cita rasa asam sehingga peningkatan level sari buah mengkudu yang ditambahkan kedalam yoghurt akan menimbulkan cita rasa yang semakin asam pula. Data ini berbanding terbalik dengan nilai $\mathrm{pH}$ dimana $\mathrm{pH}$ yoghurt pada perlakuan $\mathrm{P} 3$ (15\%) yaitu 4,3 dimana semakin meningkat cita rasa asam yoghurt maka semakin menurun nilai $\mathrm{pH}$ nya. Hal ini sesuai dengan pendapat Djaafar dan Rahayu (2006) bahwa selama proses fermentasi, bakteri asam laktat akan memfermentasi karbohidrat yang ada hingga terbentuk asam laktat. Pembentukan asam laktat ini menyebabkan peningkatan keasaman dan penurunan nilai $\mathrm{pH}$.

\section{Warna Yoghurt}

Rata-rata uji organoleptik (warna) yoghurt dengan penambahan sari buah mengkudu dengan level yang berbeda disajikan pada Gambar 3 .

Gambar 3 menunjukkan bahwa penambahan sari buah mengkudu dengan level yang berbeda berpengaruh sangat nyata $(\mathrm{P}<0,01)$ terhadap warna yoghurt. Nilai organoleptik warna yoghurt dengan penambahan sari buah mengkudu berkisar 1,82 - 3,49 yaitu pada kategori warna putih dan putih kecoklatan. Yoghurt dengan warna tertinggi ditunjukkan pada P3 (3,49\%) dan yoghurt dengan warna terendah ditunjukkan pada P0 (1,82\%). Terjadi peningkatan tingkat kesukaan warna oleh panelis seiring meningkatnya level sari buah mengkudu yang ditambahkan pada yoghurt.

Adanya penambahan level dari sari buah mengkudu menyebabkan warna putih pada yoghurt berubah menjadi putih kecoklatan. Hal ini terjadi karena sari buah mengkudu pada dasarnya sudah berwarna keruh. Hal tersebut sesuai dengan penelitian Sitompul et al. (2014) menyatakan bahwa sari mengkudu digolongkan sebagai sari yang berwarna keruh yang di sebabkan oleh adanya partikelpartikel yang terdispersi di dalamnya. Semakin tinggi

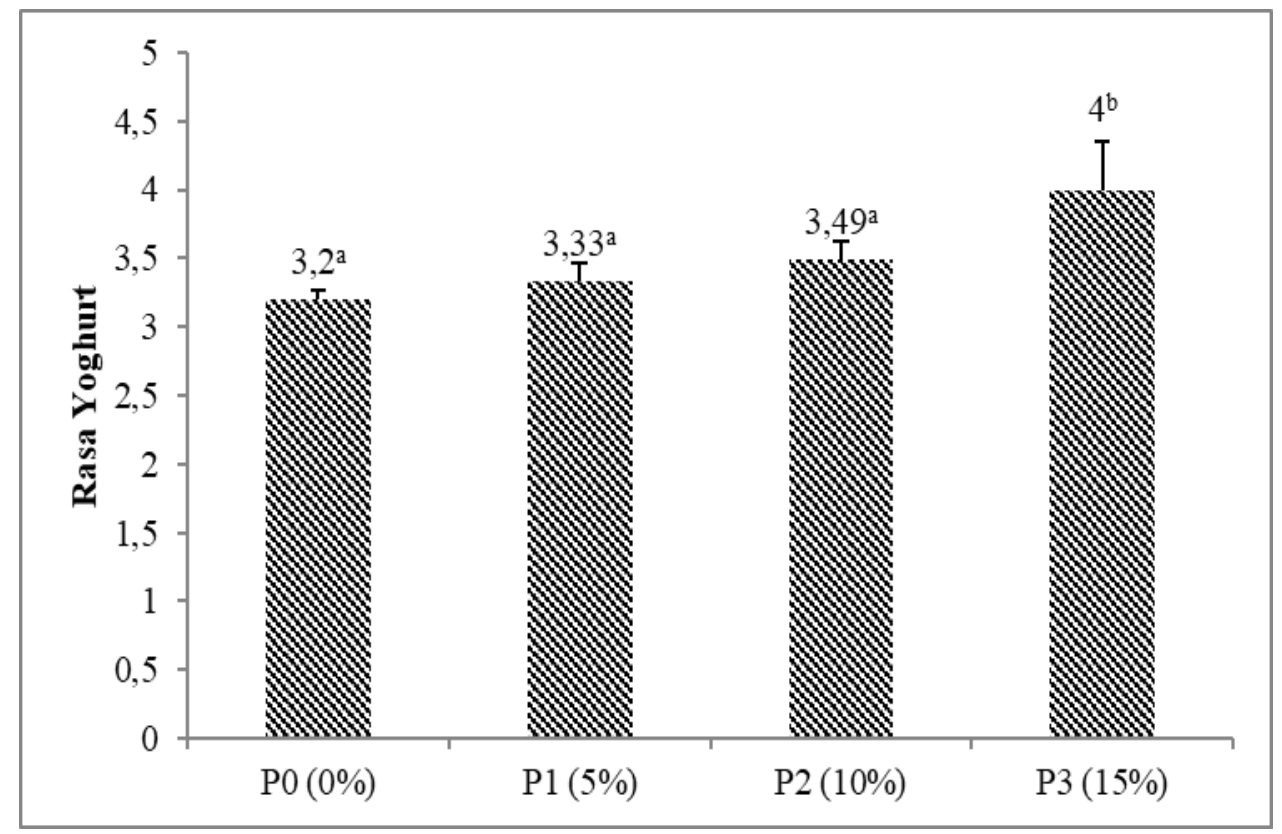

Gambar 2. Grafik hasil uji organoleptik terhadap rerata rasa yoghurt dengan penambahan sari buah mengkudu 


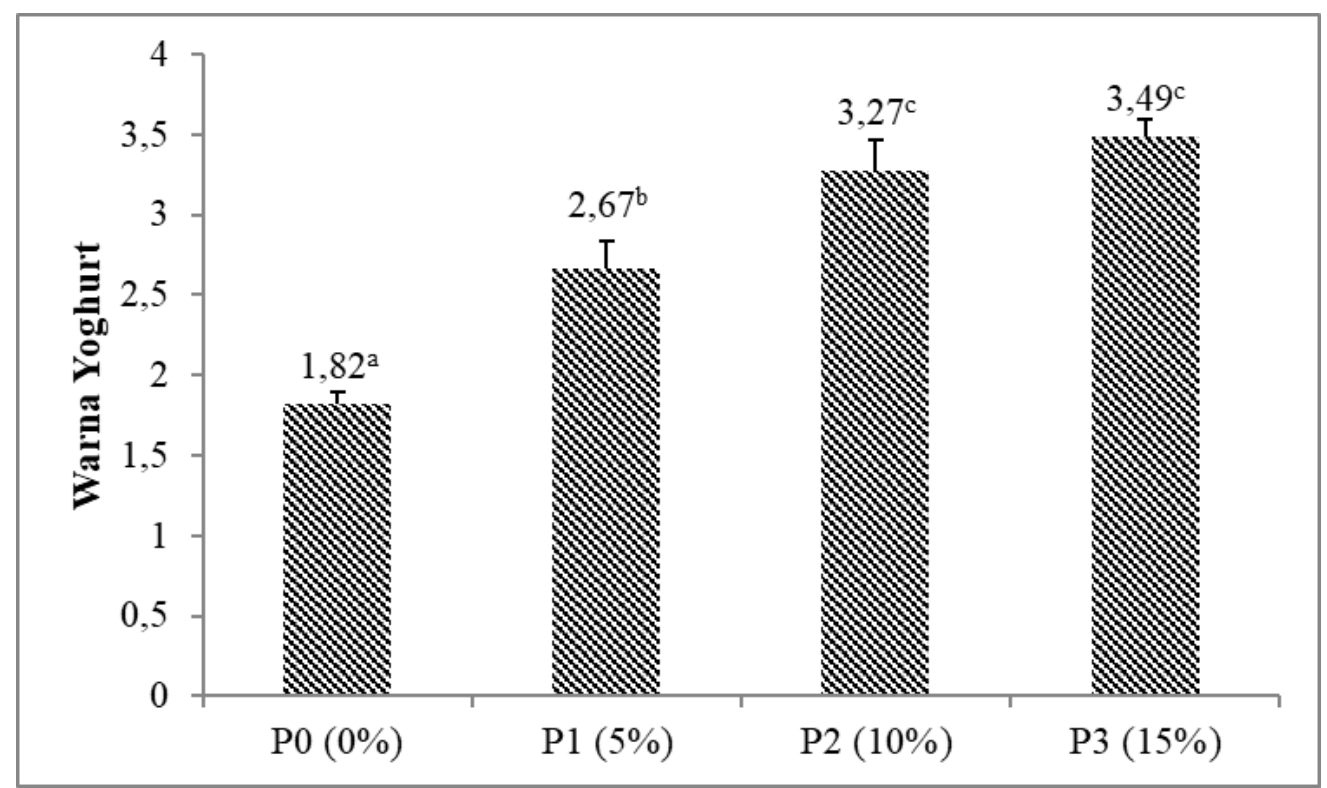

Gambar 3. Grafik hasil uji organoleptik terhadap rerata warna yoghurt dengan penambahan sari buah mengkudu

level sari buah mengkudu yang digunakan maka semakin besar pula perubahan warna yang terjadi pada yoghurt, tingkat kesukan panelis semakin besar pada perlakuan (P3) dimana warna yang dihasilkan lebih cerah di banding pada perlakuan kontrol (P0). Hal ini sesuai dengan pendapat dari Lawless dan Heymann (2010) bahwa warna merupakan salah satu parameter yang dapat digunakan untuk menilai suatu produk pangan dan dapat menunjang kualitasnya. Bahan pangan yang memiliki warna yang menarik akan menimbulkan kesan positif, walaupun belum tentu memiliki rasa yang enak. Lebih lanjut oleh Winarno (2002), secara visual faktor warna akan tampil lebih dahulu dan sering kali menentukan nilai suatu produk. Apabila suatu produk makanan memiliki warna yang menarik dapat meningkatkan selera konsumen untuk mencoba makanan tersebut.

\section{Tekstur Yoghurt}

Tekstur yoghurt dengan penambahan sari buah mengkudu pada level yang berbeda berdasarkan hasil uji organoleptik disajikan pada Gambar 4. Hasil analisis ragam menunjukkan bahwa penambahan level sari buah mengkudu (Morinda citrifolia L) pada level yang berbeda berpengaruh sangat nyata $(\mathrm{P}<0,01)$ terhadap tekstur yoghurt. Yoghurt dengan nilai tekstur tertinggi ditunjukkan pada P3 (15\%) dengan nilai 3,71 sedangkan nilai tekstur terendah ditunjukkan pada P0 (kontrol) dengan nilai 2,42.

Berdasarkan Gambar 4 dapat diketahui bahwa P0 memiliki tekstur yang kental sedangkan pada P1, P2, dan P3 memiliki nilai tekstur yang agak kental dan tidak kental. Kekentalan pada yoghurt kontrol (P0) disebabkan oleh kasein yang memiliki sifat peka terhadap keasaman ( $\mathrm{pH})$. Hal ini sesuai dengan pendapat Rukmana (2001) bahwa bila pH susu rendah sampai $\pm 4,6$, maka kasein menjadi tidak stabil dan akan terkoagulasi (menggumpal) sehingga membentuk padatan. Tekstur yoghurt pada perlakuan P1, P2, dan P3 nilai kekentalannya mulai berkurang seiring penambahan level yang diberikan, semakin banyak penambahan sari buah mengkudu yang diberikan pada yoghurt, semakin rendah pula nilai kekentalan yang dihasilkan. Penurunan kekentalan ini dikarenakan adanya penambahan sari buah mengkudu yang berupa cairan menimbulkan efek pertambahan kadar air pada yoghurt. Kadar air yang relatif tinggilah yang menjadikan nilai kekentalan menjadi rendah.

\section{Aroma Yoghurt}

Rata-rata uji organoleptik (aroma) yoghurt dengan penambahan sari buah mengkudu dengan level yang berbeda dapat dilihat pada Gambar 5.

Berdasarkan hasil analisis ragam (ANOVA) pada Gambar 5 menunjukkan bahwa penambahan sari buah mengkudu (Morinda citrifolia L) pada level berbeda berpengaruh sangat nyata $(\mathrm{P}<0,01)$ terhadap aroma yoghurt. Yoghurt dengan nilai aroma tertinggi ditunjukkan pada P3 (15\%) yakni 3,73, sedangkan yoghurt dengan nilai aroma terendah ditunjukkan pada P0 $(0 \%)$ yakni 2,69 . Di industri pangan, uji terhadap aroma dianggap penting karena dapat memberikan penilaian terhadap hasil produksinya, apakah produksinya disukai atau tidak disukai oleh konsumen. Aroma yoghurt dengan penambahan sari buah mengkudu dapat tercium karena memiliki senyawa volatil yang mudah menguap. Udara yang mengandung senyawa volatil akan mengalir secara turbulen melewati celah-celah rongga hidung dan akan terasa apabila molekul gas pada udara bergerak melewati ujung-ujung sel olfaktori (Moehyi, 1992). Berdasarkan penilaian panelis terhadap aroma yoghurt dengan penambahan sari buah mengkudu menunjukkan bahwa panelis menyukai aroma pada perlakuan P3 yaitu penambahan sari buah mengkudu sebanyak 15\%, hal ini disebabkan karena pada proses pembuatan sari buah mengkudu ditambahkan bahan lain yaitu jahe agar mengurangi bau tak sedap pada sari buah mengkudu. Jahe memiliki kandungan minyak atsiri yang memberikan aroma harum. Handrianto (2016) menyebutkan bahwa komponen utama minyak atsiri jahe yang menyebabkan bau harum adalah zingiberene dan zingiberol. Itulah sebabnya para panelis agak menyukai yoghurt dengan penambahan sari 
Rasbawati et al.

Jurnal Ilmu Produksi dan Teknologi Hasil Peternakan 7 (1): 41-46

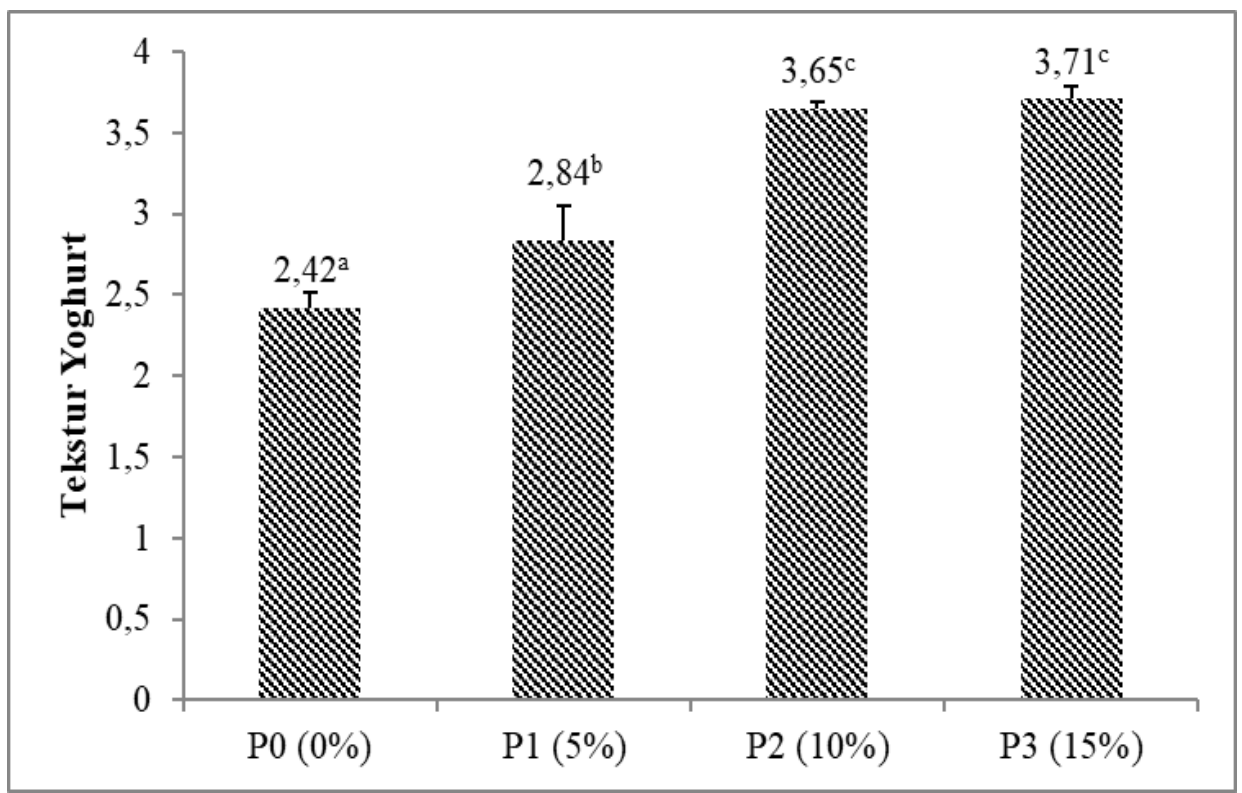

Gambar 4. Grafik hasil uji organoleptik terhadap rerata tekstur yoghurt dengan penambahan sari buah mengkudu

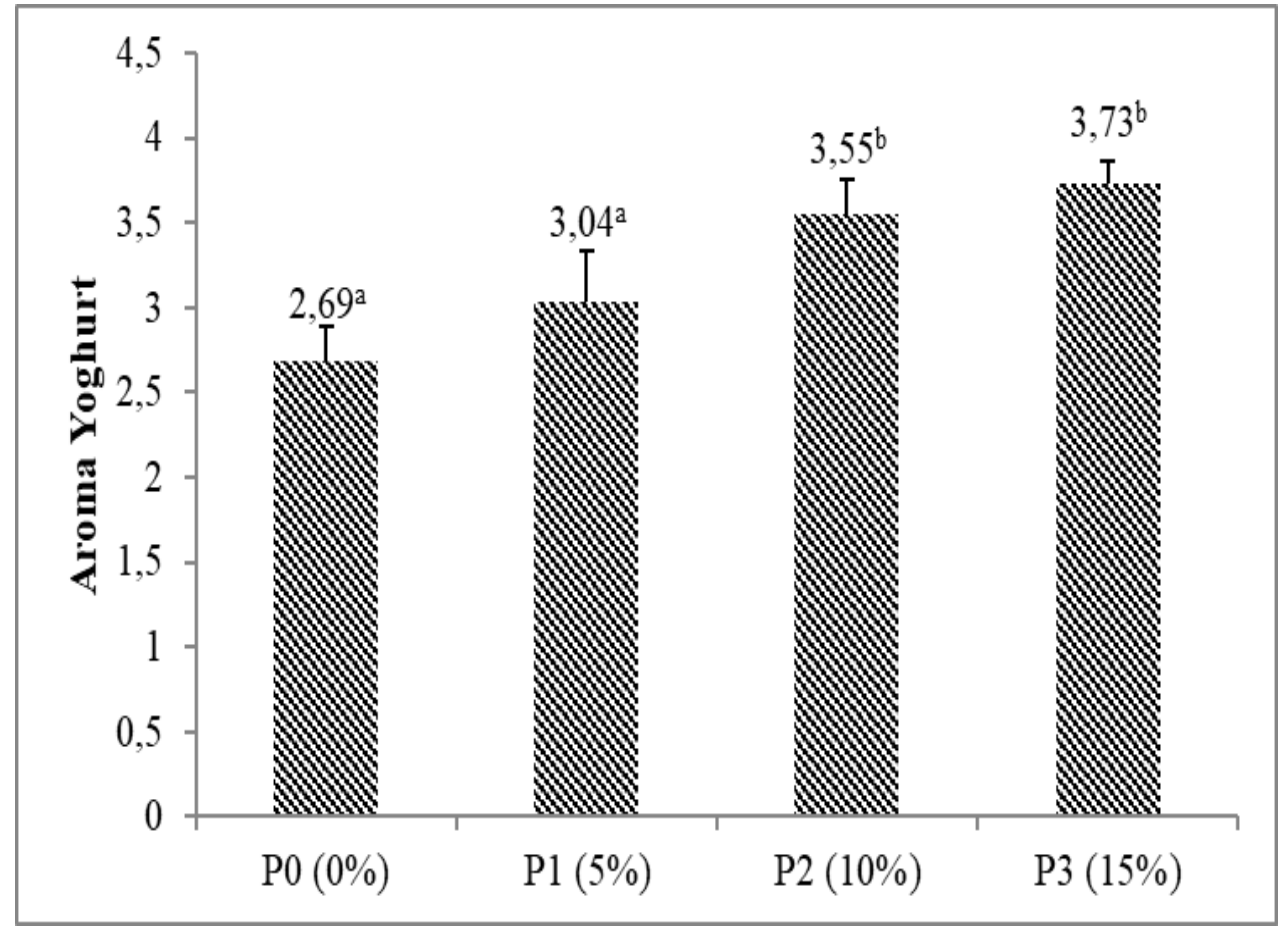

Gambar 5. Grafik hasil uji organoleptik terhadap rerata aroma yoghurt dengan penambahan sari buah mengkudu

buah mengkudu, dibanding yoghurt tanpa penambahan sari buah mengkudu.

\section{KESIMPULAN}

Berdasarkan hasil penelitian penambahan sari buah mengkudu (Morinda citrifolia $\mathrm{L}$ ) pada level yang berbeda memberikan pengaruh terhadap karakteristik organoleptik dan nilai $\mathrm{pH}$ yoghurt. Penambahan sari buah mengkudu (Morinda citrifolia L) sebesar 10\% memiliki kualitas yang paling baik. Hal ini ditinjau berdasarkan nilai $\mathrm{pH}$ dan sifat organoleptik (rasa, tekstur, warna dan aroma). Pada perlakuan terbaik tersebut menghasilkan nilai $\mathrm{pH} 4,43$ dan karakteristik organoleptik rasa (agak asam), warna (agak putih kecoklatan), tekstur (agak kental) dan aroma (khas yoghurt).

\section{DAFTAR PUSTAKA}

Ayanblu F, Wang MY, Peng L, Nowicki J, Anderson G, Nowiciki D. 2006 Antithrombotic effect of Morinda citrifolia (Noni) fruit juice on the jugular vein thrombosis induced by ferric chloride in male adult SD rats. Arteriosclerosis Thrombosis and Vascular 
Biology.;26

Badan Standardisasi Nasional. 2009. SNI Yoghurt (SNI 2981:2009). Jakarta: Dewan Standardisasi Nasional.

Djaafar, T. F dan E. S. Rahayu. 2006. Karakteristik yogurt dengan inokulum Lactobacillus yang diisolasi dari makanan fermentasi tradisional. Agros. 8 (1): 73-80.

Food Standards Australia New Zealand. 2014. Standard 2.2.3 Fermented milk products.

Handrianto P. 2016. Uji antibakteri ekstrak jahe merah Zingiber officinale var. Rubrum terhadap Staphylococcus aureus dan Escherichia coli. Journal of Research and Technologies 2(1):24.

Lawless, H, and Heymann, H. 2010. Sensory Evaluation of Food Principles and Practices Second Edition. Springer, New York.

Moehji, S. 1992.Penyelenggaraan Makanan Institusi dan Jasa Boga. Bharata. Jakarta.

Munti S, Tarsim, dan Iwan Faizal. 2010. Pengaruh ekstrak buah mengkudu (Morinda citrifolia L.) dalam menghambat pertumbuhan bakteri Vibrio harveyi secara in vitro. J. Penelitian sains vol 13 no 3d.

Roberfroid M.B. 2000 : Prebiotics and probiotics: are they functional foods? Am $j$ clin nutr Volume 71, Issue 6, 1 June 2000, Pages 1682S-1687S

Rukmana, R., 2001, Yoghurt dan Karamel Susu, Kanisius,
Yogyakarta, pp.7-14 ( 29 juli 2018)

Shovic, A.C dan Whistler, W.A. 2001. Food Sources of Provitamin A and Vitamin C in The American Pacific. Tropical science 41: 199-202.

Sitompul, N.M., Lubis, Z., dan Suhaidi, I. 2014. Pengaruh Perbandingan Sari Mengkudu dengan Sari Nanas dan Jumlah Sukrosa terhadap Mutu Minuman Serbuk Mengkudu Instan. J. Rekayasa Pangan, 2(1): 33

Surono, I. S. 2004. Probiotic Susu Fermentasi dan Kesehatan. Jakarta: Yayasan Pengusaha Makanan dan Minuman Seluruh Indonesia

Tamime and R.K. Robinson. 2007. Yoghurt Science and Technology. Third Edition. Woodhead Publishing. Cambridge.

Wahyudi, M. 2006. Proses pembuatan dan analisis mutu yoghurt. Buletin Teknik

Wang MY, West BJ, Jensen CJ, Nowicki D, Anderson G, Chen X,. 2002. Morinada citrifolia (noni): a literature review and recent advances in Noni research. Acta Pharmacologica Sinica.;23(12):112741

Winarno FG. 2002. Pangan Gizi, Teknologi, dan Konsumen. Gramedia Pustaka Utama, Jakarta. 